\title{
Introduction: Mapping Conspiracy Theories in the United States and the Middle East
}

Conspiracy theories hold that evil agents, the conspirators, secretly control or are plotting to gain control over an institution, a region, a nation, or the world. Over the past five decades such projections have received a considerable amount of scholarly attention. In fact, ever since Richard Hofstadter explored "The Paranoid Style in American Politics" (1964) in his by now classic essay, the field of conspiracy theory research has steadily grown. ${ }^{1}$ But whereas Hofstadter and most others who studied the attractions, mechanisms, and effects of conspiracism from the 1960s to the mid-1990s tended to pathologize conspiracy theories, the past twenty years have seen a reevaluation of conspiracist visions, their origins, and their cultural, social, and political functions. As a number of recent studies have shown, conspiracy theories have both a long history and were and are far more widely spread than previously assumed. ${ }^{2}$ While it is still unclear since when conspiracy theories have been part of Asian, Arab, and African cultures, in the western world at least they can be traced back to antiquity. ${ }^{3}$ What is more, such theories were and are not only believed on the fringes, but were and still are an integral part of most, if not all, societies. Finally, scholars today may differ considerably in their overall evaluations of conspiracy theory, but most would surely agree with Mark Fenster's assessment that conspiracy theories "may sometimes be on to something". 4 What Fenster means is that some

1 Cf. Richard Hofstadter, "The Paranoid Style in American Politics", in: The Paranoid Style in American Politics and Other Essays, Cambridge 1995, pp. 3-40.

2 Cf., for example, Barry Coward/Julian Swann (eds.), Conspiracies and Conspiracy Theory in Early Modern Europe: From the Waldensians to the French Revolution, Aldershot 2004; Rogalla von Bieberstein, Der Mythos von der Verschwörung: Philosophen, Freimaurer, Juden, Liberale und Sozialisten als Verschwörer gegen die Sozialordnung, Wiesbaden 2008; Peter Robert Campbell/Thomas E. Kaiser/Marisa Linton (eds.), Conspiracy in the French Revolution, Manchester 2007; Robert Alan Goldberg, Enemies Within: The Culture of Conspiracy in Modern America, New Haven, CT 2001.

3 Cf. Joseph Roisman, The Rhetoric of Conspiracy in Ancient Athens, Berkeley, CA 2006; Victoria Emma Pagán, Conspiracy Narratives in Roman History, Austin, TX 2004.

4 Mark Fenster, Conspiracy Theories: Secrecy and Power in American Culture, rev. ed., Minneapolis, MN 2008, p. 90. 
conspiracy theories are simply reflections of racism or anti-Semitism, whereas others are voiced, for purely manipulative reasons, by people who do not believe in the claims themselves. But conspiracy theories are also frequently articulations of and distorted responses to existing problems, needs, and anxieties. Thus, they must not be dismissed out of hand and ridiculed but have to be taken seriously.

In this vein, historians investigate the effects of conspiracist visions in past ages, while political scientists do the same for the present, with both of them paying special attention to conspiracy theories' role in stabilizing or destabilizing political systems. Sociologists examine the shifting status of the knowledge that conspiracy theories produce and represent and question how the Internet eases the distribution of such theories or how they contribute to the creation of counter-publics. Psychologists seek to understand if there are personality types or groups particularly prone to conspiracy theorizing, and analytical philosophers are currently struggling with the question if all conspiracy theories are intrinsically flawed, or if there are criteria by which one could distinguish between legitimate and unwarranted suspicions. Anthropologists and ethnologists investigate if conspiracy theories existed in indigenous cultures before they came into contact with the western world, how western visions of conspiracy have subsequently merged with other belief systems, and how conspiracist discourse allows people to make sense of their daily lives and to understand their position with regard to both the local and the global. Literary critics analyze the traces that conspiracist visions leave in fictional texts of all kinds, whereas scholars from cultural studies explore projections of conspiracy outside the realm of the literary, conspiracy theorizing as a cultural practice, and conspiracy theory's role in the formation of individual and collective identity. ${ }^{5}$

5 It is impossible to list all relevant studies here but they are included in the bibliography of conspiracy theory research at the end of this book. For historical studies, cf., for example, Coward/Swann, Conspiracies and Conspiracy Theory; Campbell/Kaiser/Liton, Conspiracy; Geoffrey Cubitt, The Jesuit Myth: Conspiracy Theory and Politics in Nineteenth-Century France, Oxford 1993; Markus Hünemörder, The Society of the Cincinnati: Conspiracy and Distrust in Early America, New York 2006. For political science, cf. Michael Barkun, A Culture of Conspiracy: Apocalyptic Visions in Contemporary America, Berkeley, CA 2003; Matthew C. Gray, Conspiracy Theories in the Arab World: Sources and Politics, London 2010. For sociological contributions, cf., for example, Michael Schetsche/Ina Schmied-Knittel, "Verschwörungstheorien und die Angst vor über- und unterirdischen Mächten", in: kuckuck: Notizen zur Alltagskultur, 1/2004, pp. 24-29; Andreas Anton, Unwirkliche Wirklichkeiten: Zur Wissenssoziologie von Verschwörungstheorien, Berlin 2011. For current research in psychology, cf. Viren Swami/Rebecca Coles, "The Truth Is Out There: Belief in Conspiracy 
This growing body of scholarly work has immensely increased our understanding of conspiracy theory. However, there is still a lot of work left to be done. Since most extant research focuses on one single region or culture with the vast majority of studies examining various aspects of conspiracy theorizing in the United States or drawing on American examples when examining conspiracy theory in general - we do not yet know enough about how conspiracist visions differ from one region or culture to the other, how they travel from one culture or region to the other, or how this transfer affects their forms and functions. We also possess only a very rudimentary understanding of the reasons why conspiracy theories quite obviously figure more prominently in some regions and cultures than in others. And we also do not know for certain yet if conspiracy theories are an anthropological given, as some scholars assume, or if, at least in their modern form, they emerged with the Enlightenment and spread from Europe all over the world, as the editors of and most contributors to this volume think. The situation is further aggravated by the fact that there have not been many inter- or transdisciplinary efforts to study conspiracy theories so far. In fact, scholars often seem unaware of the insights already gained in neighboring disciplines. For example, historians and political scientists working on American conspiracy theories of the nineteenth and twentieth centuries have usually neither drawn on or historicized, nor explicitly rejected what cultural studies scholars have argued about contemporary American culture. They sometimes acknowledge their work in passing but hardly ever engage with their findings or the theoretical models they have proposed.

Theories", in: The Psychologist, 23/2010, pp. 560-563; Marina Abalakina-Paap et al., "Beliefs in Conspiracies", in: Political Psychology, 20/1999, pp. 637-647; Ted Goertzel, "Belief in Conspiracy Theories", in: Political Psychology, 15/1994, pp. 731-742. Most work done in analytical or political philosophy has been collected in David Coady, Conspiracy Theories: The Philosophical Debate, Aldershot 2006. For contributions from anthropology and ethnology, cf. the essays collected in Harry G. West/Todd Saunders (eds.), Transparency and Conspiracy: Ethnographies of Suspicion in the New World Order, Durham, NC 2003. For literary studies, cf., among many others, Albert D. Pionke, Plots of Opportunity: Representing Conspiracy in Victorian England, Columbus, OH 2004; Adrian S. Wisnicki, Conspiracy, Revolution, and Terrorism from Victorian Fiction to the Modern Novel, New York 2008; Samuel Chase Coale, Paradigms of Paranoia: The Culture of Conspiracy in Contemporary American Fiction, Tuscaloosa, AL 2005. For cultural studies, cf. Fenster, Conspiracy Theories; Jodi Dean, Aliens in America: Conspiracy Cultures from Outerspace to Cyberspace, Ithaca, NY 1998; Peter Knight, Conspiracy Culture: From Kennedy to The X-Files, London 2000; Timothy Melley, Empire of Conspiracy: The Culture of Paranoia in Postwar America, Ithaca, NY 2000. 
Focusing on the United States and the Middle East, two regions where conspiracy theories have been prominent for a long time, Conspiracy Theories in the United States and the Middle East constitutes a step toward closing some of the gaps thus left. Its perspective is both comparative and interdisciplinary, as it concentrates on two different regions of the world that are nevertheless connected in manifold ways, and as it brings together scholars from Middle Eastern Studies, Anthropology, History, Political Science, Cultural Studies, and American Studies. Taken together, the essays collected in this volume offer a nuanced image of the workings of conspiracy theory in the United States and the Middle East. Because of their focus on individual cases and local conditions, they dispel a number of myths about conspiracism, especially with regard to the Middle East, by complicating the pictures painted by previous research. Since a number of contributions address conspiracy theorizing prior to 1960 , they add a historical perspective much needed in a field where most research still focuses on the present. Most importantly, they help us understand how conspiracy theories operate in different historical, cultural, political, and social contexts, alerting us to the commonalities and differences in conspiracist thinking both between the United States and the Middle East and within these nations or regions.

The volume is organized into five thematic sections. Section 1, "The United States and the Middle East", contains four essays that explore how the Middle East figures in conspiracist accounts prominent in the United States and vice versa, and how (alleged) actions by actors from one region have affected conspiracy theories circulating in the other. Aaron Winter focuses on the extreme right in the United States, Schirin Fathi on Iran, André G. Sleiman on Lebanon, and Brian Johnsrud on Dan Brown's The Da Vinci Code and its relationship to post-9/11 medievalism in the United States. The three essays in section 2, "The Politics of Conspiracy Theory", are case studies of how different kinds of political actors deploy conspiracy theories consciously or unconsciously in order to achieve their goals, that is, how they at times adapt certain theories for strategic purposes while rejecting others for the same reason. Christopher Herbert deals with vigilante committees in nineteenth-century California, Türkay Salim Nefes with political parties in contemporary Turkey, and Stephan Schmid with the Lebanese Hizbollah. Section 3, "The Promises of Conspiracy Theory", investigates different ways in which people utilize the knowledge offered by conspiracy theory to make sense of their lives. Sebastian M. Herrmann explores how the epistemic crisis to which conspiracy theory answers is dramatized in fiction, Annika Rabo examines the role of conspiracy talk in everyday discourse in Syria, and Christoph Herzog engages with visions of the "deep state" in Turkey. Sec- 
tion 4, "Travelling Theories", is dedicated to the transnational dimension of both conspiracy theorizing and conspiracy theory research. Andrew McKenzie-McHarg explores how the Illuminati conspiracy theory traveled from Europe to the United States at the end of the eighteenth century and how it was transformed during this process. In similar fashion, Barbara De Poli examines the transfer of Masonic and anti-Semitic conspiracy theories to the Arab world. Matthey Gray, by contrast, is not concerned with conspiracy theories, but discusses to what degree theories of conspiracy theory developed with regard to the United States can be used to shed light on conspiracist visions in the Middle East. His contribution thus forms a bridge to section 5, "Theorizing Conspiracy Theory", which contains four essays that consider the state of current research, including that collected in this volume, from a meta-position. Alexander Dunst argues that contemporary research has still not gone beyond pathologizing conspiracy theories; Birte Christ exposes the gendered biases of both conspiracy theory and conspiracy theory research; Mark Fenster uses recent discussions about how states might react to accusations of conspiracy to reject calls for one singular theory of conspiracy theory; and Peter Knight, finally, looks ahead and maps areas of future research. First of all, however, the introduction lays the foundation for what follows by providing an overview of the histories, forms, and origins of conspiracy theories in the United States and the Middle East, and the highly imbalanced relationship between these two regions.

\section{The Forms and Functions of American Conspiracy Theories}

From a certain perspective, the history of the United States is the history of a series of subsequent conspiracy theories that have decisively shaped the course of the country. In fact, more than a century before the nation was founded, the Puritan settlers in New England saw themselves as threatened by a devilish plot in the literal sense. Conceiving of themselves as God's chosen people, the Puritans believed that they were at the forefront of a cosmic struggle between God and Satan. Accordingly, they thought that all their enemies - for example, Native American tribes or Catholics from French Quebec - were secretly collaborating under the lead of the devil, and that all hardships that befell them - for example, epidemics or natural disasters were moves in this battle. ${ }^{6}$ This fear of conspiracy, as Robert Levine puts it,

${ }^{6}$ On Puritanism in general, cf. the contributions to John Coffey (ed.), The Cambridge Companion to Puritanism, Cambridge 2008. On Puritan conspiracy theories, cf. Goldberg, Enemies Within, pp. 1-4; Robert S. Levine, Conspiracy and Romance: Studies 
"helped the Pilgrim and Puritan colonists to create and define their community". ${ }^{7}$ As long as the enemy was located (largely) outside the community, the conspiracy theory that the Puritans believed in stabilized their community. However, when during the Salem witchcraft crisis of 1692 the enemy seemed to have infiltrated the community, the conspiracy theory fueled a mass panic and shook the community to its very foundations.

During the eighteenth century, metaphysical conspiracy theories featuring the devil were increasingly replaced by secular accounts that focused exclusively on human actors. But conspiracist fears remained important to American culture and continued to function as means of collective self-definition. ${ }^{8}$ Indeed, one can make a strong case that the United States only came into being because of a conspiracy theory. Bernard Bailyn already argued during the 1960s that

[t]he fear of a comprehensive conspiracy against liberty throughout the Englishspeaking world - a conspiracy believed to have been nourished in corruption, and of which, it was felt, oppression in America was only the most immediately visible part - lay at the heart of the Revolutionary movement. ${ }^{9}$

According to Bailyn's influential study, from the late 1750s onward, the colonists increasingly gained the impression that the king, his ministers, and the Church of England were conspiring against their and all other people's liberty - an idea that not only fueled but justified their rebellion and created a sense of collective identity. As Jodie Dean puts it, "Distrust of British authority helped produce a new 'we,' a 'we' constituted out of those sharing a fear of corruption and ministerial conspiracy, a 'we' hailed in the Declaration as those who might believe that the king was plotting against their liberty". ${ }^{10}$

in Brockden Brown, Cooper, Hawthorne, and Melville, Cambridge 1989, pp. 6-8; as well as chapter 2 in Michael Butter, Plots, Designs, and Schemes: American Conspiracy Theories from the Puritans to the Present, Berlin/Boston 2014.

7 Levine, Conspiracy and Romance, p. 6.

8 For more extended histories of American conspiracy theories than the one provided here, cf. David Brion Davis (ed.), The Fear of Conspiracy: Images of Un-American Subversion from the Revolution to the Present, Ithaca, NY 1971; Goldberg, Enemies Within. For the Early Republic, cf. also J. Wendell Knox, Conspiracy in American Politics 1787-1815, New York 1972; for the twentieth-century, cf. Kathryn S. Olmsted, Real Enemies: Conspiracy Theories and American Democracy, World War I to 9/11, Oxford 2009.

9 Bernard Bailyn, "Foreword", in: Bailyn (ed.), Pamphlets of the American Revolution 1750-1776, vol. 1, Cambridge, MA 1965, pp. vii-xii, p. x. Cf. also Bailyn, The Ideological Origins of the American Revolution, Cambridge, MA 1967.

10 Jodie Dean, "Declarations of Independence", in: Dean (ed.), Cultural Studies \& Political Theory, NY 2000, pp. 285-304, p. 297. 
As a consequence, it is hardly surprising that the Founding Fathers saw the newly established nation constantly threatened by plots involving internal or external enemies or a combination of both. This fear found its most pronounced expression in George Washington's Farewell Address of September 1796 in which Washington admonished Americans to stand united because their unity was "the point in your political fortress against which the batteries of internal and external enemies will be most constantly and actively (though often covertly and insidiously) directed [...]". ${ }^{11}$ This warning did not go unheard but proved extraordinarily prophetic. Displaying the "uniform vigilance"12 that Washington demanded, until into the second half of the twentieth century, conspiracy theorists worried about exactly that which Washington had worried about. In the 160 years after the issuing of the Farewell Address, American conspiracy theories revolved predominantly around alleged plots by domestic and/or foreign agents against the government. In these conspiracist visions, the government was almost always in great peril but had not yet fallen to the conspirators.

One prominent example of such fears occurred very shortly after the publication of the Farewell Address: the Illuminati scare of 1798-1799. ${ }^{13}$ A number of Federalist politicians and New England ministers, most prominently Jedidiah Morse, charged that the secret order of the Illuminati, driven by the desire to abolish all religion and social order, had first caused the French Revolution and was now, in league with the Democratic Republicans, busy to subvert the American republic. Motivated at least in part by these claims, Congress passed the Alien and Sedition Acts, a set of bills that allowed the president to suppress critical opinions about the government in the press and to deport foreigners suspected of subversion. In his contribution to this volume, Andrew McKenzie-McHarg investigates how the Illuminati conspiracy theory traveled from Europe to the United States, why it fell on fertile ground there, and how Jedidiah Morse adapted the arguments of European conspiracy theorists in order to make them meaningful for the new context.

In many ways, the Illuminati scare provided the pattern which most conspiracist fears would follow over the nineteenth century, as the idea that a domestic faction was actively collaborating with a foreign power and thus com-

11 George Washington, "Farewell Address", in: Don Higginbotham (ed.), George Washington: Uniting a Nation, Lanham, MD 2002, pp. 137-155, p. 140.

12 George Washington, "Farewell Address", p. 147.

13 The classic study of this scare is Vernon Stauffer, New England and the Bavarian Illuminati, Diss. Columbia University, New York, 1918. 
mitting what J. Wendell Knox has called the "cardinal sin in the United States" proved highly influential. ${ }^{14}$ Throughout the 1800 s and 1810s Democratic Republicans and Federalists continually accused each other of this crime. The Federalists usually claimed that the Democratic Republicans were conspiring with the French, and the Democratic Republicans claimed that the Federalists and the British were plotting the destruction of the American republic. The motivation of foreign powers to engage in such conspiracies was, however, only rarely seen as an anarchic desire for the destruction of social order as such (as in the case of the Illuminati). Far more frequently (as in the case of Britain and Napoleonic France), foreign powers were accused of planning the destruction of the United States in order to disqualify the unwelcome example in democracy that the country was setting to Europe where, in the eyes of the Americans, people were slaves to autocratic regimes.

Such strategic foreign conspiracies also featured prominently in various countersubversive scenarios that emerged from the 1820s onward. With the exception of the rather short-lived fear of a Masonic conspiracy and Jacksonian anxieties about the workings of a mysterious Money Power, all major conspiracy theories of the antebellum period revolved to varying degrees around exactly such foreign attempts. Between the 1830s and 1850s a considerable number of Americans became convinced that recently arrived Catholic immigrants as well as Catholics who had come to the United States before were not loyal to the republic and the Constitution but only to the pope. The pope and the monarchs of Europe, the conspiracy theorists believed, had devised a vicious plan to undermine the democratic system of the United States because they were concerned that the people in their own countries would soon demand the rights guaranteed to American citizens. ${ }^{15}$

In similar fashion and exactly at the same time, abolitionists and later Republican politicians as well were cast by proslavery activists as the (sometimes) knowing or (usually) unwitting participants in a British plot to drive the country into a civil war. According to these conspiracy theorists, the British fueled the abolitionist fervor because the internal conflict it would inevitably lead to would not only disqualify the democratic example America was set-

14 Knox, Conspiracy in American Politics, p. 316.

15 On the anti-Catholic conspiracy theory, cf. also Ray A. Billington, The Protestant Crusade 1800-1860: A Study of the Origins of American Nativism, Chicago, IL 1964; John Higham, Strangers in the Land: Patterns of American Nativism, 1860-1925, rev. ed., New Brunswick, NJ 2008; David Brion Davis, "Some Themes of CounterSubversion: An Analysis of Anti-Masonic, Anti-Catholic, and Anti-Mormon Literature", in: The Mississippi Valley Historical Review, 47/1960, pp. 205-224; Susan M. Griffin, Anti-Catholicism and Nineteenth-Century Fiction, Cambridge 2004. 
ting the world but also destroy the economic threat that the South allegedly posed for Great Britain. ${ }^{16}$

Opponents of slavery, however, also harbored a conspiracy theory. According to Republicans like Charles Sumner or Abraham Lincoln, an organization of slaveholders, the Slave Power, was plotting to nationalize slavery and possibly to extend it to the white working class. The Slave Power, these conspiracy theorists believed, had already brought the federal government under its control. Presidents, congressmen, or Supreme Court judges were either members of the Slave Power or its powerless puppets. In the accounts of these countersubversives, then, we no longer encounter a conspiracy directed against the state but one conducted by it. Apart from this deviation, however, the Slave Power conspiracy theory has a lot in common with those conspiracy theories of the time that regarded the state as not yet quite captured. Even though Lincoln and others contended that the Slave Power controlled all branches of government, they retained faith in the democratic process and held that change for the better could be brought about by elections. In fact, the Republican Party was founded exactly in this spirit. This confidence in elections distinguishes the opponents of the Slave Power from post-1960 countersubversives who usually claim that elections are only staged by those who control the government and thus offer no possibility to amend things. It aligns anti-Slave power activists with other conspiracy theorists of their time, for example with anti-Masons and anti-Catholics who also founded new parties to further their ends.

But these national, and sometimes even international, conspiracies were by no means the only ones that haunted the countersubversive imagination of antebellum America. Christopher Herbert demonstrates in his essay that the newly founded state of California experienced a series of conspiracy scares during the 1850 s. Anglo-American merchants repeatedly convinced themselves that secret societies comprising Australian and Mexican immigrants, but also politicians, were trying to or had already gained control over cities and counties. These local conspiracy theories were disconnected from those that played out on the national stage, but they followed similar patterns and articulated the same anxieties and convictions. As Herbert puts it,

16 On conspiracy theories revolving around slavery, cf. David Brion Davis, The Slave Power Conspiracy and the Paranoid Style, Baton Rouge, LA 1970; Leonard L. Richards, "Gentlemen of Property and Standing": Anti-Abolition Riots in Jacksonian America, New York 1970; Richards, The Slave Power: The Free North and Southern Domination, 1780-1860, Baton Rouge, LA 2000; Michael Pfau, The Political Style of Conspiracy: Chase, Sumner, and Lincoln, East Lansing, MI 2005; Eric Foner, Free Soil, Free Labor, Free Men: The Ideology of the Republican Party Before the Civil War, New York 1995. 
While arising out of pragmatic interests of a certain group of middle-class AngloAmerican merchants, these conspiracy theories gained widespread traction and credibility because they confirmed what Anglo-Americans already "knew": that the republic depended on free independent (white) men, and that social ills were symptomatic of challenges to the republic.

After the Civil War the fear of conspiracy diminished considerably on both the local and the national level for a couple of decades. David Brion Davis writes that "When compared with the stormy antebellum decades, the period from 1865 to 1890 exhibits a façade of stability, moderation, and pragmatic balance"17 in which conspiracist visions did not thrive. Conspiracy theories, however, gained new prominence during the economic crisis at the end of the century. For the next couple of decades they did not only follow the established pattern and blamed internal and external enemies for conspiring against the government; in many cases they also revived old enemies. Turn-of-the-century conspiracy theories targeted Masons, Catholics, bankers, blacks, and various kinds of foreigners. But new villains were also added to the picture. Due to a wave of immigration from Eastern Europe, antiSemitic conspiracy theories emerged for the first time on a larger scale in the United States. These theories have survived until today, and because of the genocidal history of the twentieth century they have received a lot of attention. Unlike in Europe, however, anti-Semitic conspiracy theories have, except for the late nineteenth century, never enjoyed much success in the United States. They have always appealed to the Ku Klux Klan and other groups on the extreme right, but overall their importance pales in comparison with conspiracist fears of Catholics or Communists.

Concerns about Communists also first emerged in the final quarter of the nineteenth century, but they only took on a conspiracist garb during the 1930s when Americans also began to worry about infiltration by Nazis. With the emergence of the Cold War, then, Communists became the primary target of American conspiracy theories. ${ }^{18}$ Whereas during the Red Scare of 1918-1919 the Communists had been cast as foreigners who wanted to instigate open insurrection, anti-Communists now worried about Americanborn Communists who secretly plotted America's doom in allegiance with

17 Davis, Fear, p. 149.

18 On American anti-Communism, cf. Richard M. Fried, Nightmare in Red: The McCartby Era in Perspective, New York 1990; Michael J. Heale, American Anticommunism: Combating the Enemy Within 1830-1970, Baltimore, MD 1990; Heale, McCarthy's Americans: Red Scare Politics in State and Nation 1935-1965, Basingstoke 1998; David Oshinsky, A Conspiracy So Immense: The World of Joe McCarthy, Oxford 2005. 
and directed by the Soviet Union. Thus, during the 1950s, American conspiracy theories still followed the pattern that had emerged at the turn to the nineteenth century: anti-Communists fought a conspiracy that united a treacherous faction of "un-American" traitors on the inside with a foreign power in an attempt to capture the government.

During the 1960s, however, the thrust of American conspiracy theories changed significantly. If earlier conspiracy theories were almost exclusively concerned with plots against the state, and in particular the federal government, recent visions of conspiracy have predominantly revolved around plots by the state, and in particular the federal government. ${ }^{19}$ No matter whether they concern the Kennedy assassination, the moon landing, the New World Order, the so-called Zionist Occupied Government (ZOG), 9/11, or the Obama presidency, post-1960 conspiracy theories usually hold that the federal government has already fallen to the conspirators and that they have effectively transformed the machinery of the state into an apparatus of oppression and exploitation. Although occasionally fueled, as in the case of Obama and ZOG conspiracy theories, by overt racism and antiSemitism, these conspiracy theories invariably articulate a profound distrust of the forces of globalization, centralized power, and the state of American democracy in general. At the same time, they often express confidence that the wrongs can still be righted and that the values of republicanism can be restored through individual human agency.

Conspiracy theories that target the federal government and other state agencies have left a broad mark on film and fiction. There are innumerable movies and novels of all kinds that foster and negotiate the fascination with plots by government officials. In his essay on Larry Beinhart's two novels about White House conspiracies - one of which was adapted into the film Wag the Dog - Sebastian M. Herrmann investigates the cultural work that these novels, and, by implication, much non-fictional conspiracy theorizing, perform. Beinhart's conspiratorial plots, Herrmann argues, are "indicative of an 'epistemic panic', a widespread cultural anxiety about the limitations of knowledge and the elusiveness of the 'real' as a fundamental social category". In similar fashion, Birte Christ also draws on fictional representations of conspiracy, Oliver Stone's film J.F.K. (1991) and Sidney Pollack's 3 Days of the Condor (1975), in order to highlight another important cultural function of conspiracist visions: the reaffirmation of a traditional, hegemonic notion of masculinity that, as the plots of these films show, disempowers women and works to restrict them to the private sphere. What is

19 On this shift, cf. Olmsted, Real Enemies, p. 4; and Knight, Conspiracy Culture, p. 58. 
more, Christ also shows that most conspiracy theory scholarship does not critique but unwittingly contributes to this project by dismissing female visions of conspiracy as hysteria and ennobling male ones by considering them interventions, however misguided and distorted, in the political sphere.

That conspiracy theory scholarship these days regards American conspiracy theories as symptomatic expressions of deeper anxieties shows that not only the parameters of conspiracist visions but also their status has changed considerably since the 1960s. Whereas conspiracy theories that saw the state threatened but not yet captured represented a legitimate form of knowledge that was articulated in farewell addresses and on the Senate floor by some of the nation's most revered leaders, those more recent theories that accuse the government of conspiring against the people constitute what Michael Barkun calls "stigmatized knowledge". ${ }^{20}$ Whereas in previous ages, accusations of conspiracy were an integral part of mainstream discourse, the term "conspiracy theory" now functions as a powerful instrument of dismissal. As Peter Knight puts it, "Calling something a conspiracy theory is not infrequently enough to end discussion". ${ }^{21}$ Accordingly, while visions of conspiracies by the state are omnipresent in contemporary American culture, they have also increasingly moved to the margins of society. One group among which they thrive is the extreme right where the feeling that the federal government is secretly controlled by Zionists or the New World Order is particularly pronounced. Aaron Winter's essay, however, does not focus on these conspiracy theories directly but explores how the extreme right, before and after 9/11, tried to forge alliances with Islamists in Arab countries and why these attempts, which have caused much concern among liberal commentators, have been almost completely unsuccessful.

The attacks of $9 / 11$ and their aftermath are also a powerful reminder that despite the paradigm shift of the 1960s there are still American conspiracy theories concerned with plots by - largely - external enemies directed against the state. While the attacks of September 11, 2001 were no doubt an actual conspiracy masterminded by Osama bin Laden and carried out by nineteen Arab men, the George W. Bush administration responded to these attacks with concocting a conspiracy theory that claimed that al-Qaeda and Iraq were secretly aligned and plotting America's doom. As this example shows, what is considered a conspiracy theory is not only determined by its internal characteristics but also by the position of those who voice it in public discourse. And while conspiracy theories that target the government are

20 Barkun, Culture of Conspiracy, p. 5.

21 Knight, Conspiracy Culture, p. 11. 
usually labeled "conspiracy theories" and thus disqualified, conspiracy theories that target "enemies" of the state frequently escape this designation.

Two contributions to this volume engage with this official conspiracy theorizing, albeit in very different fashion. By way of a close analysis of Dan Brown's megaseller The Da Vinci Code (2002) and Ron Howard's movie adaptation (2006), Brian Johnsrud explores the medievalism that permeated both American culture in general and the Bush administration in particular in the first years after 9/11, arguing that Brown's novel confirms the idea that the crusades are essential to understanding the current conflict between the West and the Middle East, but that it complicates the view of the Middle East that has become an integral part of much institutional historiography and of the Bush administration's conspiracy theory. By contrast, Alexander Dunst takes this conspiracy theory as the point of departure for a general critique of conspiracy theory scholarship. Even the revisionist studies written since the mid-1990s, he argues, continue to pathologize one form of conspiracy theorizing and thus overlook the omnipresence of another form in mainstream discourse.

\section{The Origins of American Conspiracy Theories}

"Conspiracy theories are inseparably connected with conspiracies", German sociologist Michael Schetsche contends, thereby not only implying that conspiracy theories and real conspiracies are often difficult to tell apart but also that they condition each other. ${ }^{22}$ Schetsche's argument is indeed one often made in conspiracy theory research. Trying to explain why conspiracy theories occur more frequently at certain historical moments than at others and figure more prominently in some cultures than in others, many scholars and for good reasons, as our discussion of Middle Eastern conspiracy theories below will show - point to the existence of real conspiracies. However, as far as the United States is concerned, it is difficult to explain the lasting appeal of conspiracist visions in this way. Not only is the history of the United States, especially when compared to that of Europe or the Middle East, relatively devoid of real plots; what is more, the conspiracies that did occur were usually small in scale and only fueled already existing conspiracy theories, if they had any impact on conspiracy theorizing at all. The two most prominent plots of the nineteenth century, for example - the attempt of the

22 Michael Schetsche, "Die ergooglete Wirklichkeit: Verschwörungstheorien und das Internet”, in: Kai Lehmann/Michael Schetsche (eds.), Die Google-Gesellschaft: Vom digitalen Wandel des Wissens, Bielefeld 2007, pp. 113-120, p. 114. 
abolitionist John Brown to instigate a slave uprising by staging a raid on Harper's Ferry in 1859 and the assassination of Abraham Lincoln - were both carried out by only a handful of people and merely confirmed the conspiracy theories that the defenders of slavery and its opponents had harbored for many years. ${ }^{23}$

Accordingly, if one wants to explain "America's special relationship to conspiracy theory" 24 one has to look elsewhere. We do not wish to foster notions of American exceptionalism, but we would like to suggest that the popularity and power of conspiracy theories in American culture from Puritan times to the present can be explained by the longevity and co-presence of the heritage of Puritanism, the ideology of republicanism, and an epistemological paradigm that presupposes a direct link between cause and effect and thus holds that everything that occurs has been intended exactly that way. We do not contend that these three factors are the only sources of American conspiracism, but we consider them the most important ones. We are convinced that they explain why conspiracy theories, which were as popular in France, England, and most other European countries as they were in the United States during the eighteenth and nineteenth centuries, have retained their appeal in America but not in Europe. ${ }^{25}$

Over the past decades, scholars from different disciplines have demonstrated the importance of Puritanism for numerous aspects of American life. ${ }^{26}$ Many Puritan ideas have been secularized over the centuries and thus continue to shape American culture and identity until today. For example, the notion of American exceptionalism has its roots in the Puritans' selfunderstanding as God's chosen people. Much the same is true for the American propensity for conspiracy theorizing. Displaying the Manichean thinking

23 The perception of real conspiracies was, however, a factor, albeit not the only one, in bringing about the shift from conspiracy theories that detect plots against the state to those that are concerned with plots by the state during the 1960s and 1970s. As Kathryn Olmsted puts it, "government officials provided fodder for conspiracism by using their powers to plot - and to conceal - real conspiracies" (Real Enemies, p. 234).

24 Olmsted, Real Enemies, p. 3.

25 Within the scope of this introduction it is impossible to explore these three factors and their complex interplay in detail. For a far more detailed version of the argument made here, cf. chapter 1 in Butter, Plots, Designs, and Schemes.

26 Cf. Sacvan Bercovitch, The Puritan Origins of the American Self, New Haven, CT 1975; Tracy Fessenden/Nicholas F. Radel/Magdalena J. Zaborowska (eds.), The Puritan Origins of American Sex: Religion, Sexuality and National Identity in American Literature, New York 2001; George McKenna, The Puritan Origins of American Patriotism, New Haven, CT 2007. 
characteristic of conspiracy theorizing, the Puritans saw themselves at the forefront of the struggle between good and evil, and they were convinced that all their enemies were secretly aligned. Moreover, they believed that history unfolded according to a divine plan. Nothing happened by chance but because it had been predestined by an inscrutable God. Thus, Puritan thinking was organized along the parameters that Michael Barkun has identified as characteristic of all conspiracism: nothing happens by accident, nothing is as it seems, and everything is connected. ${ }^{27}$

The major difference between the Puritans' metaphysical conspiracy theory and later secularized versions is that the Puritans believed that ultimately God controlled the conspirators. Whereas accounts from the eighteenth century onward usually do without supernatural actors and regard the conspirators as those who are pulling the strings, the Puritans held that God allowed the devil and his minions to torment the Puritans whenever his chosen people was not living up to his high expectations. They conceived of their affliction as a corrective punishment that was meant to make them mend their ways and not to destroy them. Thus, for the Puritans, the detection of conspiracies was both a cause of concern and a confirmation of their sense of election and mission. Albeit in a modified form, the same still is true today. Contemporary conspiracy theorists worry about the plots they reveal, but the very fact that they have been capable of detecting these plots signals that they are different. They may not have been elected by God, but they are elevated from the unsuspecting masses because of their special knowledge and thus have the obligation to fight the conspiracy. Accordingly, historian Robert Alan Goldberg considers the originally religious and later nationalized sense of mission the most important source of American conspiracism. ${ }^{28}$

The second major influence on American conspiracy theories has been the ideology of republicanism, which was an important element of eighteenth- and nineteenth-century American political culture and whose impact, much like Puritanism's, is still discernible today. ${ }^{29}$ The prototypical American fear of political parties, for example, which dominated American politics far into the nineteenth century and fueled various conspiracy theories, resulted from this political theory which the American colonists adopted from the

29 On tepublicanism, cf. Gordon

29 On republicanism, cf. Gordon S.Wood, The Creation of the American Republic, 1776-1787, New York 1972; J. G. A. Pocock, The Machiavellian Moment: Florentine Political Thought and the Atlantic Republican Tradition, Princeton, NJ 1975. 
English Whig party. Unlike liberalism, republicanism conceived of humans as social beings that formed communities not out of necessity, but because it was a part of their nature. Accordingly, the proponents of republicanism demanded that everybody should have the common good in mind at all times - a principle they saw violated by political parties. As Michael Pfau puts it, "parties were naturally suspect because they represented only a part of the people - a faction - that was likely to look to its own good in preference to the good of the whole". 30

Parties, however, were only the most obvious and outward manifestation of a danger that adherents of republicanism worried about in more general terms: "corruption". In the ideology of republicanism, corruption figured as diametrically opposed to the one value the success of a republic hinged on: "virtue". Republican ideology postulated a perpetual struggle between virtue and corruption and held that only the former could prevent the rise and eventual triumph of the internal and external enemies that the latter would inevitably lead to. In this rather pessimistic view, adherents of republicanism were confirmed by the study of history. Even more so than their predecessors in Renaissance Italy, whose destinies they had carefully examined, Americans were aware that "traditionally republics were short-lived, subject to cyclical decline, and vulnerable to the plottings of internal and external enemies". ${ }^{31}$ Because of their form of government, their openness when compared with autocratically ruled nations, and the absence of standing armies, republics were seen as all too quickly destroyed through the conspiracies of corrupted individuals and groups on the inside and outside.

The fear of plots and schmemes, then, was inscribed into the ideology of republicanism, and since republicanism was so important for eighteenthand nineteenth-century American political culture, conspiracy theories were widespread, as various scholars have observed. Robert Levine, for example, writes that "Republican ideology and discourse [...] played a crucial role in perpetuating the fear of conspiracy in early national and antebellum culture"; and Daniel Walker Howe even speaks of a "conspiracy paradigm" when discussing republican ideas among the American Whigs, a political party of the 1830 s and 1840 s. 32

Levine's and Howe's references to the antebellum period indicate that republicanism did not, as an earlier generation of scholars had assumed,

\footnotetext{
30 Pfau, Political Style, p. 41.

31 Levine, Conspiracy and Romance, p. 10.

32 Levine, Conspiracy and Romance, p. 40; Howe, Political Culture, p. 79.
} 
rapidly lose in importance at the beginning of the nineteenth century. ${ }^{33}$ Indeed, republicanism changed over the course of the nineteenth century but it remained highly influential until the Civil War after which the fear of party together with many other elements of republican thought slowly waned. Republicanism's basic tenet, however, the conflict between virtue and corruption, has survived and continues to fuel conspiracy theories until today. As J. G. A. Pocock, one of the most influential scholars of republicanism, has convincingly argued, it is still palpable in President Eisenhower's warnings against the workings of the "military-industrial complex", a concept that is integral to countless contemporary conspiracist visions. ${ }^{34}$

The final factor in accounting for American culture's predilection for conspiracy theories is an epistemological paradigm that emerged in the eighteenth century and that also remains influential in the United States until today. This paradigm has been most thoroughly described by Gordon Wood in his essay "Conspiracy and the Paranoid Style: Causality and Deceit in the Eighteenth Century". As Wood demonstrates, throughout this century, conspiracy theories produced officially accepted knowledge. The most enlightened thinkers of the age had abandoned the idea that history was unfolding according to a divine plan, but they were not ready yet to accept the impact of chance, contingency, or of systemic factors. Instead they propagated a mechanistic worldview in which "[a]ll human actions and events could now be seen scientifically as the products of men's intentions". ${ }^{35}$ Assuming that "cause and effect were so intimately related that they necessarily shared the same moral qualities", 36 these thinkers dismissed the possibility that intentions and results could be more than occasionally at odds. If a group's actions constantly produced effects different from those the group allegedly wanted to produce, one was justified to assume that the group was hiding their real intentions. Hence, when faced with series of harmful events

33 Other scholars that make a strong case for the survival of republicanism far into the nineteenth century are Linda Kerber, Women of the Republic: Intellect and Ideology in Revolutionary America, 5th ed., Chapel Hill, NC 1997; Jeffrey Ostler,"The Rhetoric of Conspiracy and the Formation of Kansas Populism", in: Agricultural History, 69/1995, 1, pp. 1-27; Sean Wilentz, Chants Democratic: New York City and the Rise of the American Working Class, 1788-1850, New York 1984; Jean H. Baker, Affairs of Party: The Political Culture of Northern Democrats in the Mid-Nineteenth Century, Ithaca, NY 1983.

34 Pocock, "Civic Humanism and Its Role in Anglo-American Thought", in: Politics, Language and Time: Essays on Political Thought and History, London 1971, pp. 80-103, p. 97.

35 Wood, "Conspiracy", p. 416.

36 Wood, "Conspiracy", pp. 417-418. 
whose originators denied all evil intentions, people were compelled to conclude that a conspiracy was underway. As Wood puts it: "The belief in plots was not a symptom of disturbed minds but a rational attempt to explain human phenomena in terms of human intentions and to maintain moral coherence in the affairs of men". ${ }^{37}$

This epistemological paradigm proved remarkably resilient in both Europe and America. Whereas Wood suggests that it disappeared early in the nineteenth century, Geoffrey Cubitt (for France) and Ralf Klausnitzer (for Germany in particular and Europe more generally) have demonstrated that it continued to generate knowledge considered legitimate until the early twentieth century. ${ }^{38}$ According to Klausnitzer, it only lost its influence in Europe when the social sciences began to offer systemic explanations for effects hitherto ascribed to the hidden intentions of individuals. This, however, might be exactly the reason why the paradigm retained its hegemonic position far longer in the United States and why it continues to produce appealing, albeit by now disqualified, knowledge there until today. After all, resistance to structural explanations of all kinds is deeply ingrained in American culture because they would shake one of its central pillars: the belief in the power of individuals to shape not only their own lives but the course of history. During the 1950s, for instance, many social scientists claimed that brainwashing was possible because, as Timothy Melley has shown, this assumption allowed them to discuss systemic effects on individuals without giving up the belief in a self-contained, autonomous self (which was seen as being manipulated by an even stronger self, that of the brainwasher). ${ }^{39}$ Unsurprisingly, therefore, politicians also still rejected systemic factors. As Senator Joseph McCarthy, one of America's most notorious conspiracy theorists of that period, put it, "History does not just happen. It is made by men - men with faces, and the only way the course of history can be changed is by getting rid of the specific individuals who we find are bad for America". ${ }^{40}$

37 Wood, "Conspiracy", p. 429.

38 Whereas Cubitt explicitly rejects Wood's argument ("Quite simply, this recession [that Wood postulates] shows very little signs of having happened during the nineteenth and early twentieth centuries" ["Conspiracy Myths", p. 18]), Ralf Klausnitzer does not refer to Wood at all (cf. Poesie und Konspiration: Beqiehungssinn und Zeichenökonomie von Verschwörungsszenarien in Publizistik, Literatur und Wissenschaft 1750-1850, Berlin 2007). However, focusing on Germany, he discusses the emergence of the same epistemological paradigm (esp. pp. 66-98) and traces its repercussions into the twentieth century.

39 Cf. Timothy Melley, "Brainwashed! Conspiracy Theory and Ideology in the Postwar United States”, in: New German Critique, 35/2008, 1, pp. 145-164.

40 McCarthy qtd. in Olmsted, Real Enemies, p. 107. 
Since then, of course, even American culture has become more receptive to structural explanations, and naïve insistence on the power of individuals to shape the course of history is no longer acceptable in scientific as well as in parts of public discourse. But as the traditional post hoc ergo propter hoc logic of contemporary conspiracy theories shows, the eighteenth-century paradigm discussed here remains attractive. In fact, as Peter Knight has demonstrated, the idea that individuals can put their intentions into practice without any unwarranted side-effects both informs and is confirmed by the official (al-Qaeda did it) and unofficial (the government did it) conspiracy theories about $9 / 11$. The two narratives of what happened that day and who is to be held responsible for it may be diametrically opposed as far as the allocation of guilt is concerned. Structurally, though, both rely "on a traditional model of highly efficient individual intentional action" and thus affirm "a vague ideological disposition toward understanding causality and responsibility in terms of pure intentional agency". 41

Puritanism, republicanism, and the specific epistemology just discussed can be considered the most important origins of the American propensity for conspiracy theorizing, especially since these three factors did not exist in isolation next to each other. On the contrary, the epistemological paradigm, for example, provided the underpinning for republican fears of conspiracy, while the fact that the political theory facilitated conspiracist visions surely stabilized the epistemological paradigm. Moreover, from the eighteenth century onward, virtually all non-fictional indictments of conspiracy can be said to have assumed the form of the "republican jeremiad", a blend of the jeremiad, the narrative mode in which the Puritans expressed their fear of declension, and republican concerns about corruption. ${ }^{42}$ Republican jeremiads bemoan the present state of society by contrasting it with the glorified time before the conspiracy began, but they also express the hope that the conspiracy can still be foiled if only the people wake up to the danger and begin to actively resist it. Jedidah Morse's exposure of the Illuminati plot, Abraham Lincoln's "House Divided" speech, Joseph McCarthy's Wheeling speech, and the online documentary Loose Change are all republican jeremiads, and they all assume that individuals can shape history by putting their plans into practice. Thus, it is the combination of Puritanism, republicanism, and a par-

41 Peter Knight, "Outrageous Conspiracy Theories: Popular and Official Responses to $9 / 11$ in Germany and the United States", in: New German Critique, 35/2008, 1, pp. 165-193, pp. 176, 178.

42 Sacvan Bercovitch, The American Jeremiad, Madison, WI 1978, p. 128. 
ticular epistemological paradigm that accounts for the continued presence of conspiracy theories in American culture.

\section{The United States and the Middle East}

The United States is both a clearly defined geographical unit and a nation state; the "Middle East", a term coined by Alfred Thayer Mahan, an American historian, in 1902, is neither. It comprises a great variety of states and, reaching from the Eastern Mediterranean to the western parts of South Asia, is characterized by the blurredness of its geographical boundaries. In a certain sense, therefore, the Middle East only exists from a western point of view. ${ }^{43}$ Thus, for the scholar of conspiracy theory, speaking of "the Middle East" only makes sense when talking about American conspiracy theories that imagine the region precisely as homogeneous as the term implies, or when one is very generally concerned with processes of transfer from the "West", an equally fuzzy term, to the region. If one is interested, however, in the precise mechanisms and functions of conspiracy theories within the Middle East, one needs to look at individual states or specific local contexts. Accordingly, except for Barbara De Poli and Matthew Gray who seek to establish a general (historical respectively contemporary) framework, the other six contributions on the Middle East are dedicated to various states within the region.

What is more, a comparative approach to conspiracy theories in the United States and the Middle East must take into account the imbalance of power, in political, economic, academic-scientific, military, and many other terms, between these two entities. But not only is the United States far more powerful than the Middle East; it also exerts more power in and on that region than any other western country. While this may sound like a truism, it is worth remembering that the predominant role of the United States within the region was established only relatively recently. While U.S. special envoy Patrick Hurley noticed as early as May 1943, after visiting Egypt, that Great Britain would soon "no longer possess within herself the essentials of power needed to maintain her traditional role as the dominant influence in the

43 On the genesis of the term "Middle East" which in today's usage roughly encompasses Syria, Palestine, Israel, Jordan, Iraq, the Arabian peninsula, Egypt, Turkey, Iran, and possibly also Afghanistan and Pakistan, cf. Roderic Davison and his fatalistic statement on the obvious unpracticability cum unavoidability of the term "Middle East": "Intentional vagueness sometimes has advantage as a tent-like cover for unformulated possibilities of future action or inaction" ("Where is the Middle East?”, in: Foreign Affairs, 38/1959-1960, pp. 665-675, p. 675). 
Middle East area", ${ }^{44}$ it was only at the end of the 1970 s - and after some intermittent steps such as Britain's renunciation of the Palestine mandate in 1947 and its disastrous involvement in the failed Suez intervention of 1956 that the United States, under the impression of the Soviet invasion of Afghanistan, finally assumed "the lonely burden of protecting western interests in the Persian Gulf that Great Britain had shouldered" throughout the preceding decades. ${ }^{45}$ The demise of the Soviet Union during the early $1990 \mathrm{~s}$ then removed the United States' lone remaining competitor for influence in the region. In recent years, since the attacks of September 11, 2001, the Middle East has become more important than ever for the United States. It has become not only the central focus of American foreign policy, ${ }^{46}$ but, as Melanie McAlister argues, it has come to perform an important function for America's self-understanding: faced with its own internal diversity and race issues, the United States 'needed an 'outside' to mark its boundaries; that outside was the Middle East". ${ }^{47}$

The imbalance of power between the United States and the Middle East is mirrored by how they figure in each other's conspiracy theories. For American conspiracy theories, the Middle East is only of very limited importance. Of course, after 9/11 the Bush administration promoted the conspiracy theory that Osama bin Laden's al-Qaeda and Saddam Hussein's Iraq were secret allies, but, as Alexander Dunst reminds us in his contribution, this fantasy escaped the label "conspiracy theory". In narratives that are labeled accordingly, the Middle East features occasionally, but even then its inhabitants are bereft of agency. Many American post-9/11 conspiracy theories revolve

44 Qtd. in Douglas Little, American Orientalism: The United States and the Middle East Since 1945, Chapel Hill, NC 2008, p. 119.

45 Little, American Orientalism, p. 147.

46 Cf. also Brian Johnsrud's article in this volume. Emmanuel Todd argues, very much in the vein of intellectual French anti-Americanism, that it is the military decline of the U.S. that obliges it to make the Middle East an object of its aggression as it is a region known for its military incapabilities (Weltmacht USA: Ein Nachruf, München 2003, p. 172).

47 Melanie McAlister, Epic Encounters: Culture, Media, and U.S. Interests in the Middle East, 1945-2000, Berkeley, CA 2001, p. 259; she also comments on the importance of the Middle East for the racialized and gendered discourse of nationalist expansion in the United States (p. 275). What is more, even U.S. political scientists who sympathize with the basic tenets of U.S. policy in the Middle East will agree that in many ways not only political Islam, but also "September 11 was the price [the United States] paid for winning the Cold War and the strategies [it] chose" (Rachel Bronson, Thicker Than Oil: America's Uneasy Partnership with Saudi Arabia, Oxford 2006, p. 9). 
around the Middle East, claiming, for example, that the attacks on the Pentagon and the World Trade Center were orchestrated in order to wage war in Iraq and Afghanistan, but in these accounts the Arab terrorists, if they are part of the scenario at all, are merely puppets whose strings are pulled by Americans. At first sight, Arabs are given a more active role in religious conspiracy theories as they circulate among millennial Christians in the United States. ${ }^{48}$ Much like the Puritans three hundred years ago, these fundamentalist Christians believe in a cosmic struggle between the forces of good and evil. More precisely, they are convinced that the Anti-Christ will spearhead a plot against Israel and the United States in which many Middle Eastern countries will be involved. However, the Anti-Christ is rarely ever imagined as coming from a Middle Eastern country; reflecting remnants of the Cold War he is far more frequently imagined to be Russian, for example in Tim La Haye's immensely successful Left Bebind series. Thus, Arabs tend to be reduced to mere pawns in this scenario as well.

By contrast, the United States has been crucial to conspiracy theories circulating in the Middle East during the last decades. In fact, one might argue that it is amply proven - for example, by many contributions to this volume that one cannot write a history of U.S.-Middle Eastern relations without taking conspiracy theories into account. As we discuss in detail below, the real and alleged plots of the United States are one of the most important reasons why conspiracy theories are so prominent in the region. Yet, before we delve deeper into Middle Eastern conspiracy theories it must be stressed that, just as there must be histories of the United States in which conspiracy theories are merely a footnote, there must be histories of U.S.-Middle Eastern relations and the Middle East itself that pay no heed to conspiracy theories. ${ }^{49}$ This is not the right place to address in detail the question of Orientalism but we should keep in mind Said's remark that Orientalism can be an academic discipline, a binary way of thinking that essentializes "the West" and "the East", and a medium of control and dominance. ${ }^{50}$ Since conspiracy theories in the Middle East reflect the serious imbalance of power between the United States and the Middle East, speaking about their relationship in terms of conspi-

48 For an extended discussion of metaphysical New World Order conspiracy theories, cf. Barkun, Culture of Conspiracy, pp. 39-64.

49 A number of recent works prove that this is well possible. Cf., for example, Rashid Khalidi, Resurrecting Empire: Western Footprints and America's Perilous Path in the Middle East, London 2004; Ussama Samir Makdisi, Faith Misplaced: The Broken Promise of U.S.-Arab Relations: 1820-2003, New York 2010.

50 Edward W. Said, Orientalism, New York 1978, p. 2. 
racy theory alone runs the danger of contributing to the cementation of this hierarchy. The same is true, however, for touching on Middle Eastern conspiracy theories in passing only or ignoring them altogether, which is why we turn to them now.

\section{The Origins of Middle Eastern Conspiracy Theories}

If one believes Daniel Pipes, whose study The Hidden Hand: Middle East Fears of Conspiracy was until recently the only monograph available in English on the subject, the matter is very simple indeed. For Pipes, Middle Eastern conspiracy theories are not the "result of political structures, which in turn are the result of historical impacts, the effects of external dynamics, state-society relations, and political culture", as Matthew Gray has recently argued, 51 but the result of regional idiosyncrasies, originating from "Zoroastrian, Manichean, and Mazdak sources" and a deep-seated psychological disorder, that is, paranoia. ${ }^{52}$ Somewhat contradictorily, though, Pipes also argues that these conspiracy theories are at the same time strategically deployed: they function as a perilous weapon to attack the state of Israel. In order to prove this, Pipes repeatedly unfolds a panorama of ill-founded Middle Eastern anxieties about an alleged plan to conquer large parts of the Middle East in order to establish a "Greater Israel". 53

As many critical commentators have observed, Pipes, a prominent spokesman of the neo-conservative camp in the U.S., known amongst other as founder of the inquisition-minded institution Campus Watch, does so for strategic reasons himself. Driven by the desire to disqualify any justified objections against Israel's policies, he focuses only on exaggerated and extremely vicious Arab positions vis-à-vis Israel, thereby both simplifying and distorting the complex Middle Eastern political landscape, and laying a smokescreen over the real reasons of the Israel-Arab conflict. In fact, while Pipes draws on an astounding variety of sources (including many newspapers in Arabic language) and thus presents conclusive evidence of the Middle Easterners' proneness to conspiracy theorizing, he comes dangerously close to the techniques of conspiracism himself in that he uses a continuous time frame, a universalizing geographical perspective, and assumes the ubiquity of conspiracism. At one point, for example, he deals with Egypt in the years

51 Gray, Conspiracy Theories, p. 8.

52 Pipes, The Hidden Hand: Middle East Fears of Conspiracy, Basingstoke 1996, p. 292.

53 Cf., for example, Pipes, Hidden Hand, pp. 49, 68-69. 
1952, 1981 and 1990, with Iran in the years 1979 and 1989, and finally with Jerusalem in 1929 and 1969 on one page. ${ }^{54}$

Pipes is right in one respect, though: Israel and the Palestine question are of immediate relevance to the history and politics of the Middle East and in particular to U.S.-Middle Eastern relations, and therefore also to the forms and functions of conspiracy theories in the region. Pro-Israeli voices, antiZionists and the (larger or smaller) rest may not be able to agree on much, but they would all agree that "No matter how one turns the kaleidoscope of U.S.Arab relations, one always returns, or is returned to, the picture of Palestine". ${ }^{55}$ As a consequence, much Middle Eastern conspiracy theorizing is connected to the heated debates about Israel's legitimacy. But, first, the matter is far more complex than Pipes insinuates; and, second, there are other factors that need to be taken into account if one wants to understand the prominence of conspiracy theories in the Middle East.

Although the history of conspiracy theories in the Middle East prior to the second half of the twentieth century has yet to be written, it is clear that such theories circulated in the region before the foundation of the state of Israel in 1948. Yet, just as with anti-Semitism and Arab nationalism more generally, conspiracy theories became virulent and powerful only with the rise of the Zionist-Palestinian struggle. ${ }^{56}$ Barbara De Poli demonstrates in her contribution to this volume that conspiracy theories were absorbed in

54 Cf. Pipes, Hidden Hand, p. 14. Cf. Aaron Winter's piece in this volume for a similar assessment of this point. It also has to be noted that Pipes' pro-Zionism has not remained uncontested. It finds its counterpart in the academic world in scholars such as John Esposito who tend to idealize or at least belittle militant Islam. As Henry Munson pointedly puts it: "Reading Pipes, one could easily believe that Muslim hostility toward Israel is simply a matter of anti-Semitism. Reading Esposito, one would never know that anti-Semitism is indeed a serious problem in the Islamic world" "'Between Pipes and Esposito", in: ISIM [International Institute for the Study of Islam in the Modern World] Newsletter, 10/2002, p. 8.)

55 Makdisi, Faith Misplaced, p. 5.

56 For a general outline of the trajectory of anti-Semitism in the twentieth-century Middle East and a rich bibliography on the topic, cf. Gudrun Krämer, "Antisemitism in the Muslim World: A Critical Review", in: Die Welt des Islams: International Journal of the Study of Modern Islam, 46/2006, pp. 243-276. Cf. also Klaus Faber et al. (eds.), Neu-alter Judenhass: Antisemitismus, arabisch-israelischer Konfliket und europäische Politik, Berlin 2006; Meir Litvak/Esther Webman, From Empatby to Denial: Arab Responses to the Holocaust, New York 2009. Recent debates in the United States have stressed allegedly new "Islamofascists". Cf., for example, the polemical work by Norman Podhoretz, World War IV: The Long Struggle Against Islamofascism, New York 2007. 
Arabic-speaking countries only slowly, but then with a sudden outburst of productivity from the 1940 s onwards. De Poli identifies two main routes of the Arab world's appropriation of "western" conspiracy theories: on the one hand, anti-Masonic literature that traveled to Arab lands in the late nineteenth and early twentieth centuries, and, on the other hand, full-blown anti-Semitism injected by German Nazi propaganda from the 1920s onward. De Poli shows that both anti-Masonic and anti-Semitic writings were initially received only at the margins of society, but with the Jewish-Arab war and the proclamation of the state of Israel both became closely linked and have received much attention from the Arab media ever since. Especially the notorious Protocols of the Elders of Zion have since the 1950s become the centerpiece of conspiracy theorizing in the Arab world.

It would be wrong to say, though, that the Arab world thus still clings to a conspiracy theory that has, thankfully, long lost its mainstream appeal in Europe and North America. For once, as De Poli also shows, Arab conspiracy discourse constitutes a unique blend of anti-Semitism and anti-Masonism that does not only rely on European texts such as the Protocols but that has, in recent decades, been affirmed and embellished by countless Arab texts, many of them openly fictional, others allegedly factual. Moreover, Middle Eastern anti-Semitic conspiracy theories have different targets and different motivations than the ones that once thrived in Europe and North America and continue to exist there on the margins of society. Matthew Gray points out in his contribution that whereas anti-Semitic arguments in the United States these days focus on Jewish banking, finance, and informal power, Middle Eastern anti-Semitic conspiracy theories concentrate very specifically on Israel's actions and intentions.

However, even though the Israeli-Palestinian question as the central pivot of U.S.-Middle Eastern relations for now and for the foreseeable future is an important engine of conspiracist visions in the regions, there are others forces driving such visions that one needs to take into account as well. To begin with, there are the strategic interests of the United States, as well as of other western nations, in the region - for example, in a steady and cheap oil supply - that exist independently of the alliance with Israel and are at times even at odds with it. To protect these interests, the United States in particular launched a couple of clandestine operations in the region in the years following World War II, the most notorious of them being the CIA-led coup d'état of 1953 that removed Iran's prime minister Mohammad Mosaddeq from power. Unlike in the United States where, as we have argued, the impact of real plots on conspiracy theories has been negligible, the impact of such "real conspiracies" on the Middle Eastern predilection for conspiracy theorizing 
cannot be overestimated. ${ }^{57}$ Next to the conflict with Israel, it is the single most important source of Middle Eastern conspiracism. The occurrence of actual plots in the past nourishes the belief in conspiracies, as it fosters the tendency to interpret convoluted and undesired political circumstances in conspiratorial terms and makes the public receptive to the "exposure" of new schemes by well-established villains. In this situation, political leaders are naturally tempted to articulate conspiracy theories, whether they believe in them themselves or not.

The case of Iran, a country where conspiracy theories are propagated on a large scale by the state, illustrates well both the significance of past plots and the strategic deployment of conspiracist discourse in the present. Mahmoud Ahmadinejad may refer to Zionism as a major evil in the world, but he can only do this so frequently because the history of Iran, and especially the public memory of not only the coup of 1953 but also the coups of 1908 and 1921, which were also exerted under strong foreign influence, provides a fertile ground for a public mobilization of this kind. Schirin Fathi, in her contribution to this volume, shows that conspiracy theories have been part of Iranian nationalism even before the time of the Shah. Refuting the idea that Iran is "addicted" to conspiracy theories because of the Shia's marginalization and persecution by the Sunni majority in early Islamic history, ${ }^{58}$ she singles out the CIA's Operation Ajax of 1953, which has left deep scars in collective memory, as the major influence on Iranian conspiracism.

But Iran is not only the country in the region where conspiracy theories are handled as an important tool of political mobilization. The Lebanese Hizbollah is another striking example. Hizbollah, a radical military-political Shia movement that came into being in the early 1980s in southern Lebanon as a resistance movement against Israeli occupation, defined itself from the start as a close ally of Iran and adopted its grand theories of conspiracy. However, as Stephan Schmid demonstrates in his essay, in particular from

57 The United States also have to shoulder the historical burden of French and British imperialism, in particular the secret Sykes-Picot treaty of 1916 in which Great Britain and France defined their respective spheres of imperialist control. Bassam Tibi argues (not really convincing, though) that - when the document was diclosed by the Soviets in 1917 - the public outrage in the Middle East was the starting point for conspiracism in the region (Die Verschwörung: Das Trauma arabischer Politik, Hamburg 1993, p. 3).

58 This argument is implied by Sadik J. al-Azm who writes that "power was in fact usurped from Imamu Ali and his heirs through a series of dirty conspiracies" ("Orientalism and Conspiracy", in: Graf/Fathi/Paul (eds.), Orientalism and Conspiracy, p. 18). 
the 1990s onwards, Hizbollah has put less emphasis on grand theories in the Iranian fashion and come to use "operational" conspiracy theories, or, as he puts it, theories that are "not the reflection of a bizarre, irrational, and intransigent anti-western and anti-Zionist outlook, but a very rational medium of propaganda and political maneuvering adopted by the Party of God in the course of its changing role in the domestic and regional political arena". Whereas all of Hizbollah's conspiracy theories excoriate Israel, they are primarily addressed at the internal public and meant to strengthen Hizbollah's political position within Lebanon and its political landscape.

Lebanon is also the subject of André G. Sleiman's essay, which delves deeply into the intricacies of the country's civil war (1975-1990) and investigates how international power politics, which regarded Lebanon as a theater for proxy wars in the Middle East and beyond, were perceived from different Lebanese perspectives and interpreted in conspiracist fashion. Henry Kissinger, U.S. Secretary of State in the years 1973-1977, was identified by major Lebanese politicians, of both Christian and Muslim denomination, as a vile manipulator. A widespread, but unsubstantiated persuasion existed in Lebanon according to which Kissinger had not only triggered the civil war but intended to destroy the Lebanese model of Muslim-Christian conviviality by dividing Lebanon into two confessional states. While the Christian narrative centers on the fatal consequences of a Christian exodus from Lebanon, the Muslim one stresses the potential advantages for Israel's policy. Such a scheme, thus ran the conviction of many in Lebanon, was to stabilize Israel's position in the Middle East as its sectarian identity would then have seemed less peculiar.

Besides demonstrating how the Israeli question and the experience of real plots interact in fueling conspiracy theories in the region, these three examples show that the conspiracist visions circulating throughout the Middle East are far from simplistic or uniform, as Pipes would have it. They are highly complex projections that are at times strategically deployed and at others naively believed, but that are invariably adapted to the specificities of the national, and at times even local, contexts from which they emerge and for which they perform various kinds of cultural work. It is therefore of the utmost importance to proceed with due caution when generalizing about the forms and functions of Middle Eastern conspiracy theories.

\section{The Forms and Functions of Middle Eastern Conspiracy Theories}

Generalizing about conspiracy theories in the Middle East, one could also assume, is so difficult because the region's conspiracist visions have been far less well researched than those of the United States. We may not know 
enough about American conspiracism yet, but we know far more about it than about the Middle Eastern variant. Moreover, whereas scholars from different disciplines have over the past decades developed theories and models to account for and describe American conspiracy theories, no such models exist for the Middle Eastern context. As Matthew Gray argues in his article, scholars can draw on concepts developed for the United States (and other western countries) and originally applied to cases of conspiracism there, and he encourages them to do so because it will prevent them from falling into the trap of essentializing Middle Eastern conspiracy theories. Gray thus sees "potential for $[\ldots]$ the transferability and transposability of explanations for conspiracy theories across any cultures, not least of all the U.S. and the Middle East". Nevertheless, he also sees "strict limitations" for such transfers, as they run the danger of disregarding local specificities. What is needed, one might therefore conclude, is more research that draws on detailed case studies to theorize Middle Eastern conspiracism in general.

However, from our vantage point, the opposite is the case. The more we know about specific Middle Eastern conspiracy theories, their structures, targets, and audiences, the more difficult it becomes to identify characteristics shared by all of them. Apart from the observations that conspiracy theories are not native to the Middle East, but that this way of making sense of the world has traveled there from Europe and has then been adapted to regional circumstances, and that Middle Eastern conspiracy theories reflect and to a certain extent cement the imbalance of power between the United States (and "the West" in general) and the region, no generalizations are possible. The essays on the Middle East collected in the volume at hand challenge, rather than confirm existing generalizations. Thus, instead of defining general characteristics that do not stand closer scrutiny, we wish to stress four features that, from our current position, are integral to many, but not to all Middle Eastern conspiracy theories, and we discuss how the case studies presented here complicate them.

First, Middle Eastern conspiracy theories, as Ervand Abrahamian observed almost twenty years ago, treat interior "politics as a puppet show in which foreign powers control the marionettes - the local politicians - by invisible strings". ${ }^{59}$ Although Abrahamian referred only to Iran, his observation is certainly true for many, maybe even for most conspiracy theories circulating in the region. No matter whom or what the conspiracy theory focuses on,

59 Ervand Abrahamian, "The Paranoid Style in Iranian Politics", in: Abrahamian (ed.), Khomeinism: Essays on the Islamic Republic, Berkeley, CA 1993, pp. 111-131, p. 111. 
the American government, or at least parts of it, or "the West" more generally is almost always lurking somewhere in the background and usually cast as the mastermind behind the plot. However, not all conspiracy theories follow this pattern, as Annika Rabo and Christoph Herzog show in their contributions to the volume. Rabo demonstrates that people in Syria share conspiracy narratives that articulate dissatisfaction with the malfunctioning of the state and that blame corruption among Syrian politicians, rather than the schemes of foreign powers. Christoph Herzog shows that despite Turkey's strong democratic record and viable press, conspiracy theories abound in that country. They revolve not only around "outward forces", but also engage with the "deep state" - a concept that relates to power groups, particularly in the adminstration and the military, accused of steering state and society according to their allegedly privileged understanding of what Turkey is meant to be. Drawing on the work of the Turkish writer and intellectual Erol Mütercimler, Herzog admits that, of course, Turkish conspiracy theories also occasionally accuse foreign forces of meddling with Turkey's fate. But, for one, Herzog argues that Mütercimler's conspiracist master narrative of "the West against Turkey" follows classical anti-imperialist lines of argumentation and thus could be regarded as "essentially a nationalist vulgarization that is ultimately derived from the Marxist theoretical debate on imperialism and reinforced by the popularization of the Huntington thesis of the clash of civilizations". Moreover, even in Mütercimler's account, not all Turkish nationals are merely pawns; some of them are actors pursuing goals of their own.

Second, Matthew Gray has recently argued, and indeed does so in this volume, too, that a distinguishing feature of conspiracism in the Middle East is that conspiracy theories serve as a powerful tool of political mobilization for the state or powerful state-like organizations. Faced with a continuously diminishing legitimacy, Gray suggests, "[states] have adopted their own conspiracism also as a tool of state symbolism, legitimacy-building and control". ${ }^{60}$ Indeed, Middle Eastern state machines frequently deploy conspiracy theories for political ends, and the invectives of Gaddafi, Assad, or Ahmadinejad, who habitually blame(d) foreign agents for causing internal unrest, are often reported on by the media in Europe and North America. However, Gray's valid observation has to be modified in two respects. As Alexander Dunst reminds us in his essay, the Bush government, continuing a longstanding American political tradition, also formulated a conspiracy theory when it suggested that Iraq and al-Qaeda were secretly plotting against the

60 Gray, Conspiracy Theories, p. 12; also cf. chapter 5 in this volume, pp. 272-289. 
United States. He suggests that the only difference between the Bush administration's conspiracist vision and the visions of Middle Eastern leaders was that the former was not labeled "conspiracy theory" whereas the latter were. Accordingly, he concludes that, as in the Middle East, conspiracy rhetoric "has been part of mainstream politics from its beginnings, and continues to be so today". Moreover, conspiracy theories articulated by the state to maintain control are not always as successful as western news reporting tends to imply. As Schirin Fathi shows, state conspiracy propaganda in Iran may have strongly increased under the Ahmadinejad regime, but there are indicators that it has at the same time lost much of its appeal among the Iranian public, in other words, that it falls on deaf ears.

Third, and closely related to the previous point, one might think that unlike in the western world, conspiracy theorizing is not a fringe phenomenon in the Middle East, but that it permeates society on all levels and independent of affiliation with political camps. Again, there is much to be said in favor of this observation, since Middle Eastern conspiracy theories are often uncritically believed not only by the disempowered but also by political and cultural elites. Yet, as we pointed out above, at least as far as the United States is concerned, the delegitimization of the knowledge produced by conspiracy theorizing is a fairly recent development. Until the 1950s, American conspiracy theories, too, permeated all levels of society and all political camps, and as the example of the Bush administration shows, this has not completely changed until today, the only difference being that some visions do and others do not escape the derogatory label "conspiracy theory". Moreover, the observation that in the Middle East conspiracy theories are ubiquitous often implies the assessment that Middle Easterners cast themselves invariably as the passive and helpless victims of foreign plots. This, however, is not necessarily the case. As Annika Rabo's contribution makes clear, Middle Eastern conspiracy theories do not only occasionally revolve around domestic villains. Rabo's analysis of "conspiracy talk" in Syria, that is, everyday talk of ordinary Syrians about conspiracies by powerful others, shows that such talk is often quite prosaic and frequently deals with tangible threats. In fact, many people, especially educated males, tend to invent new elements and bring the conspiracy narratives into a direct and meaningful relationship with their personal lives as a form of entertainment, thus giving in to what Mark Fenster, for the American context, has described as the "conspiracy rush", as playful engagement with an alleged plot as if it was real. ${ }^{61}$ What is

61 Fenster, Conspiracy Theories, p. 156. 
more, when people say that "It has all been planned" they stress not only their powerlessness vis-à-vis "the system" or "the authorities" but combine it with confessions of intense self-flagellation. "Blaming 'us' is the flip side of blaming 'them"', Rabo concludes, and so her study confirms that conspiracy theories indeed permeate society, but in a fundamentally different way than it is generally assumed.

Fourth, and finally, it has been argued that whereas western conspiracy theories from the eighteenth century onward have been an epiphenomenon of secularization, that indeed conspiracy theories emerged in their modern form only because of the secularizing force of the Enlightenment, Middle Eastern conspiracy theories are different in that they are metaphysical conspiracy theories because of their connection to political Islam. While it is true that political Islam, thriving since the 1970s, has taken up conspiracy theorizing and made it even more pervasive in the public realm, the matter is, once again, more complex. To begin with, as the example of fundamentalist Christians in the United States mentioned above indicates, religious conspiracy theories continue to exist in the western world as well. In addition, political Islam, roughly defined as an ideology which strives to base politics on the premises and prescriptions of the Islamic religion, emerged in the nineteenth century. Thus, there is no natural link between political Islam and conspiracy theorizing, as the latter became part of the former's agenda only recently. Moreover, political Islam must be understood as an attempt of the Muslim world to come to terms with the challenges of modernity. "Islam", whatever it may mean to the individual person, is thus conceived by Muslims as an essential part of the Muslim heritage and identity. Accordingly, "political Islam", far from corroborating a case of Islamic exceptionalism, is intrinsic to the Muslim experience of a secularizing world. Much of Islamic ideology today is nothing else but an "islamicizing" discourse that provides a religious garb for secular themes. Finally, there is no compulsory link between political Islam and conspiray theories. Türkay Nefes' essay on the Dönme shows that the mainstream Islamic Justice and Development Party (AKP), in power in Turkey since 2002, explicitly distances itself from certain conspiracy theories. Nefes describes how the very small crypto-religious group of the Dönme (allegedly pretending to be Muslims, but practicing a particular version of Judaism inside the group) have, because of their religious and cultural liminality, been regarded as potentially disloyal to the Turkish "nation-state" since the 1920s and have become a central element in Turkish conspiracy theories. Interviews that Nefes led with important representatives of major political parties corroborate that conspiracy theories revolving around the Dönme are propagated by radical parties of nationalist 
(National Action Party, MHP) or Islamist (Felicity Party, SP) leanings, whereas the AKP has moved away from such interpretations. ${ }^{62}$

Middle Eastern conspiracy theories, then, are publicly acceptable forms of interpreting political, economic, and social contexts within the region and in its relation to the world beyond. They are containers or vehicles for specific arguments and specific anxieties, and they help to arouse the feeling of a commonly shared destiny. Contrary to common assumptions, they do not automatically render Middle Easterners the passive victims of foreign plots but also imbue them with agency. And as everywhere else, Middle Eastern conspiracy theories must be taken seriously and have to be studied closely because they often "address real structural inequities, albeit ideologically, and they may well constitute a response, albeit in a simplistic and decidedly unpragmatic form, to an unjust political order, a barren or dysfunctional civil society, and/or an exploitative economic system" ${ }^{63}$ This is not to say that conspiracy theories in the Middle East, as well as elsewhere, are not at times vicious and dangerous. The problematic role that conspiracy theories, particularly in their many anti-Semitic variations, play in Middle Eastern societies is not to be belittled. The same, however, is true for the United States where the media and large parts of the public accepted and helped promote the Bush administration's "official" conspiracy theory about Iraq in 2002 and 2003. But that conspiracy theories at times have fatal consequences is one more reason why they have to be taken seriously by academics.

62 This is, of course not to deny that the conspiracy theories promoted by radicalized Islam are often of the especially vicious and anti-Semitic kind. The major producer and exporter of "classical" crude anti-Semitic conspiracy theories is Saudi Arabia and its role in this regard would have deserved closer scrutiny.

63 Fenster, Conspiracy Theories, p. 90. 